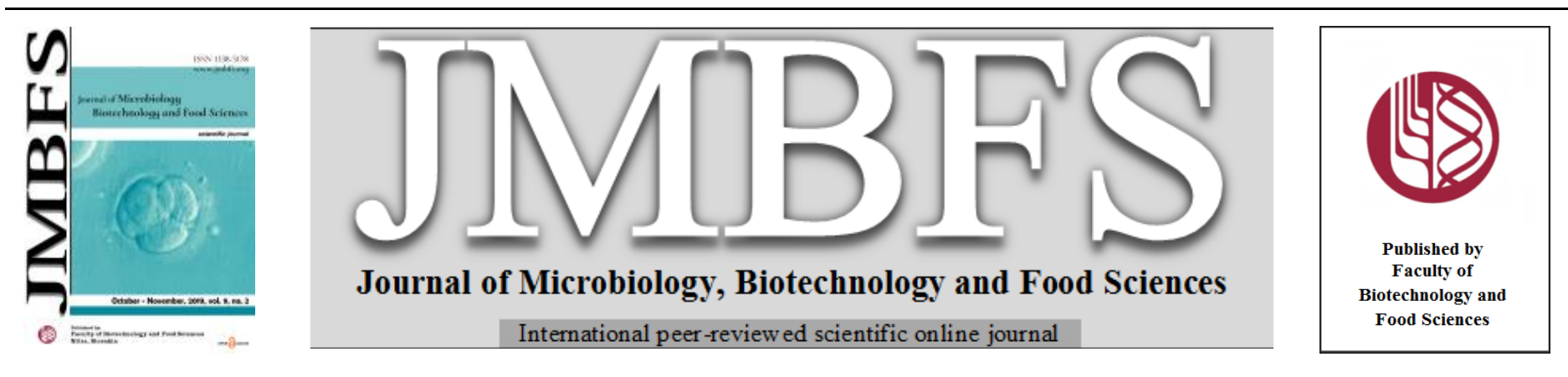

\title{
MOLECULAR CHARACTERISATION OF PROBIOTIC LACTOBACILLUS FERMENTUM ISOLATED FROM HOME MADE CURD
}

\author{
Meera N Subramanyam ${ }^{l}$ and Charitha devi Mekala* \\ Address(es): Charitha Devi Mekala, \\ ${ }^{1 *}$ Sri Venkateswara University, Department of Virology, Tirupati, 517 502, Andhra Pradesh, India. +91 9640210730.
}

*Corresponding author: charithamekala@gmail.com

doi: $10.15414 / j m b f s .2020 .9 .4 .848-855$

\section{ARTICLE INFO}

Received 8. 11. 2018

Revised 3. 7. 2019

Accepted 26. 8. 2019

Published 3. 2. 2020

\section{Regular article}

OPEN $\partial_{\text {ACCESS }}$

\begin{abstract}
The present study was undertaken to explore the probiotic potential of Lactobacillus isolated from traditional homemade curd. A total of 32 lactic acid bacterial isolates were screened from homemade curd collected from various regions of chittoor district, Andhra Pradesh, India. Most of the bacterial isolates were found to be gram positive, catalase negative and were preliminarily evaluated for their probiotic potential like acid tolerance, bile tolerance, thermo tolerance, osmo tolerance and antibiotic susceptibility. Among all the 32 isolates, 9 isolates viz. $\mathrm{L}_{1}, \mathrm{~L}_{2}, \mathrm{~L}_{3}, \mathrm{~L}_{4}, \mathrm{~L}_{5}, \mathrm{~L}_{6}, \mathrm{~L}_{7}, \mathrm{~L}_{8}$, and $\mathrm{L}_{9}$ were found to be having promising probiotic activity were further screened for antagonism against enteropathogens. One of the isolate (Lactobacillus spp $\mathrm{L}_{2}$ ) with significant probiotic properties, antagonistic activity was characterized by $16 \mathrm{~S}$ rRNA sequence analysis and was identified as Lactobacillus fermentum. The bacteriocin produced by Lactobacillus fermentum was purified by a process of ammonium sulfate precipitation and chromatography techniques. The study revealed the possibility of using bacteriocin as a food preservative and the Lactobacillus fermentum strain as probiotic.
\end{abstract}

\section{INTRODUCTION}

Bacteriocins from Lactic Acid Bacteria (LAB) isolated from traditional foods of India have proven its applicability in biopreservation (Jamuna and Jeevaratnam, 2005). The curd is an Indian traditional fermented milk product that used as a main food sources in our routine life. The fermented milk products are probiotics that contain viable lactic acid bacteria (LAB) and its metabolic byproducts act as an antioxidant, immune modulator and antimicrobial agents. Probiotics have become a major topic of lactic acid bacteria (LAB) research over the past 10 years, which include the genera of Lactobacillus and Bifidobacterim. There have been interests in commercial utilization of Lactobacillus strains isolated from traditional naturally fermented dairy products, which possess health-promoting effects. However to provide health benefits, Lactobacillus strains, which are mostly delivered in a food system, must overcome physical and chemical barriers in the gastrointestinal tract, especially acid and bile stresses (Del piano et al., 2006). Thus, there is a growing interest worldwide in the use of probiotic bacteria for their various beneficial influences on animal and human health.

Lactobacilli are wide spread in nature and many species have found applications in the food molecular techniques involving gene sequencing are now the "gold standard". Over the past decades a number of strains of LAB have been incorporated in a wide range of food products for human and animal nutrition. As the probiotic capacities are strain-dependent, methods for identifying LAB at the strain level are of great importance, especially for the quality control of approved strains, to avoid health risks and misleading claims, as well as for the description of new strains. Now a days the main focus for identification has moved from phenotypical to genotypical methods as the latter generate more sensitive and accurate results. Gram-positive lactobacilli belong to the general category of lactic acid bacteria. They are found in a variety of habitats, including the gastrointestinal tract and some strains are extensively used in food industry and pharmacy due to their healthful properties (Walter et al., 2000). Recently, many efforts have been made to search potential probiotic Lactobacillus strains from dairy products. For this purpose, simple and reliable identification methods are required (Nakatawa, 1994; Heilig, 2002). Conventional biochemical and physiological tests (Verthier and Ehrlich, 1999; Kandler and Weiss, 1986) clearly have some limitations in discriminating large number of isolates showing similar physiological characteristics. Therefore, many studies have focused on the application of molecular biology techniques for the rapid identification of Lactobacilli (Andrighetto, 1998). The DNA- DNA hybridization technique has improved knowledge on taxonomic relationships between Lactobacillus species, but this technique is still time-consuming and labours- intensive (Song et al. 1999). Besides, various methods such as DNA sequencing, fatty acid analysis and RFLP have been established and applied to the identification of probiotics (Yeung, 2002). Recently, rRNA genes have been generally accepted as the potential targets for identification and phylogenetic analysis of bacteria (Amann, 1995; Burton et al., 2003). Sequencing analysis of the $16 \mathrm{~S} r$ RNA genes has been used to determine the diversity and dynamics of LAB in food (Chen and Hoover, 2003; Jung-Min, 2010).

Bacteriocins produced by this LAB are natural peptides that exert bactericidal activity against pathogenic bacteria and this fact creates the possibility of improving their characteristics to enhance their activity and spectra of action (Saavedra et al., 2004). In order to avoid confusion with therapeutic antibiotics, which can potentially illicit allergic reactions in humans and other medical problems, bacteriocins are produced by bacteria and are normally not termed as antibiotics (Deraz et al., 2005). Bacteriocin production could be considered as an advantage for food and feed producers in sufficient amounts and these peptides can kill or inhibit pathogenic bacteria that compete for the same ecological niche or nutrient pool. This role is supported by the fact that many bacteriocins have a narrow host range, and is likely to be most effective against related bacteria with nutritive demands for the same scarce resources (Deegan et al., 2006) Purification of the bacteriocins is helpful for the knowledge of the mechanism of action, structure and other characteristics, which helps to isolate the bacteriocin biosynthetic genes.

In recent times, the concept of biodiversity in a particular ecosystem has been articulated through the use of phylogenetic tree maps based on gene sequences. Owing to the considerable economical importance of LAB, many researchers are now actively working on these bacteria using an array of genetic tools. Moreover chromosomal genes of interest have been characterized providing a new insight into the genetic organization of LAB.

This study was designed to screen the potential probiotic bacteriocinogenic Lactobacillus spp from homemade curd sample that can able to inhibit enteropathogens and also the Lactobacillus spp was identified using 16S rRNA sequence analysis. The purification of bacteriocin from identified Lactobacillus fermentum may exert beneficial effects for mankind. 


\section{MATERIAL AND METHODS}

\section{Isolation and Identification of Bacterial strains}

Curd samples were collected under aseptic conditions and were serially diluted, $100 \mu \mathrm{l}$ of $10^{-6}$ dilution from each sample was plated in triplicate on DeMan Rogosa Sharpe (MRS) agar and incubated at $37{ }^{\circ} \mathrm{C}$ for $24 \mathrm{~h}$ (De Man et al. 1960). The colonies on MRS agar plates were examined morphologically and microscopically. The colonies were streaked on MRS agar to check the purity. The pure cultures were preserved using $20 \%$ glycerol for further study (Pal et al., 2005).

\section{Screening of probiotic properties}

To study the probiotic properties of Lactobacillus spp, the cultures were grown in MRS broth by changing $\mathrm{pH}$, temperature, bile and salt concentrations (Chesson et al., 2002).

\section{Acid tolerance}

Tolerance of isolated Lactobacillus strains to acidic $\mathrm{pH}$ was determined by growing the strains at $37^{\circ} \mathrm{C}$ for $24-48 \mathrm{~h}$ in acidic MRS broth adjusted to four different $\mathrm{pH}$ values (pH 2, 3, 4 and 5) and by maintaining $\mathrm{pH} 7.0$ as control (Xanthopoulos $\boldsymbol{e t}$ al. 2000; Papamanoli et al., 2003). After 24 h of incubation, the growth was measured at $600 \mathrm{~nm}$ using spectrophotometer and the survival (viable number) of the Lactobacillus strains were enumerated by pour plate counts using two fold serial dilutions (Conway et al., 1987 and Brashears et al., 2003). The experimental analysis was carried out in duplicates. The results are shown as the average of two replicates. A reference strain was used to consider as positive control.

\section{Thermo tolerance}

To study the thermo tolerance, the isolated bacterial cultures were grown in MRS broth and incubated at different temperatures like $30^{\circ} \mathrm{C}, 40^{\circ} \mathrm{C}, 50^{\circ} \mathrm{C}$ and $60^{\circ} \mathrm{C}$ for 24 $48 \mathrm{~h}$. The cultures grown at $37{ }^{\circ} \mathrm{C}$ considered as control. After incubation, the growth was measured at $600 \mathrm{~nm}$ to select the thermo tolerant Lactobacillus strains and the survival rate of the Lactobacillus strains were enumerated by pour plate counts using two fold serial dilutions. The experiments were carried out in duplicates. The results are shown as the average of two replicates.

\section{Bile tolerance}

To determine the effect of bile on the growth of the Lactobacillus spp, strains were cultivated in MRS broth enriched with different concentrations of bile salt (sodium thioglycolate) $1 \%, 2 \%$ and $3 \%$ at $37^{\circ} \mathrm{C}$ for $24 \mathrm{~h}$. MRS broth without bile was considered as control. Bacterial growth was monitored by measuring absorbance at $600 \mathrm{~nm}$ using spectrophotometer, simultaneously the viable count of the Lactobacillus spp were expressed in colony forming units per millilitre (cfu/ml) (Succi et al., 2005). The experiment was repeated twice and each reading represents the average of two replicates.

\section{Osmo tolerance}

To determine osmo tolerance of Lactobacillus spp strains were grown in MRS broth with different concentrations of $\mathrm{NaCl}$ like1\%, 1.5\%, 2\%, 2.5\% and 3\% respectively and incubated at $37{ }^{\circ} \mathrm{C}$ for $24 \mathrm{~h}$. After incubation, the cell turbidity was measured at $600 \mathrm{~nm}$ (Axelsson, 1998; Erkkila and Petaja, 2000) and the survival rate of the Lactobacillus strains were enumerated by pour plate counts in colony forming units per mililiter (Tsai et al., 2005). The Lactobacillus spp grown in MRS broth with $0 \%$ $\mathrm{NaCl}$ was considered as control. The experimental analysis was carried out in duplicates with the average of two replicates.

\section{Detection of antimicrobial activity of the selected Lactobacillus isolates}

The inhibitory activity of the selected Lactobacillus isolates was determined using agar well diffusion assay against the enteropathogens Escherichia coli, Enterococcus faecalis, Pseudomonas fluorescence, Pseudomonas aeruginosa, Staphylococcus aureus, Salmonella typhimurium and Proteus mirabilis (Subramanyam et al., 2014). The test bacteria were inoculated in nutrient broth and incubated at $37^{\circ} \mathrm{C}$ for $24 \mathrm{~h}$. Cell free supernatant of the isolates was obtained by centrifugation at $5000 \mathrm{Xg}$ at $4{ }^{\circ} \mathrm{C}$ for $20 \mathrm{~min}$ and was collected for bacteriocin assay. Supernatant was adjusted to $\mathrm{pH} 7$ with $1 \mathrm{~N} \mathrm{NaOH}$ to nullify the acid activity. The cell free supernatant thus obtained was used for detection of antibacterial activity. The petridishes containing MRS agar was seeded with the selected Lactobacillus isolates. Wells were created on the seeded agar using incinerated agar borer. $50 \mu \mathrm{l}$ of the supernatant was filled into the wells of the inoculated plates and incubated for $24 \mathrm{~h}$ at $37^{\circ} \mathrm{C}$ and the inhibition zones around the wells was measured. Antimicrobial activity was determined as arbitrary units (AU) per ml. One AU was defined as the reciprocal of the highest dilution showing a clear zone of growth inhibition.

\section{Characterization and Identification of the Strain}

The strain with probiotic properties and antagonistic activity was identified by 16S r RNA sequence analysis. The genomic DNA from selected bacterial culture was extracted according to the method described by Park et al., (2010). 16S r RNA gene was amplified by polymerase chain reaction (PCR) using the forward primer F (5'-AGAGTTTGATCMTGGCTCAG3') and reverse primer R (3' AAGGAGGTGWTCCARCC) 5'. Amplification was performed in a DNA thermal cycler at $95{ }^{\circ} \mathrm{C}$ for $3 \mathrm{~min}$, followed by 30 cycles at $94{ }^{\circ} \mathrm{C}$ of $30 \mathrm{~s}, 1 \mathrm{~min}$ at $52{ }^{\circ} \mathrm{C}$ and $90 \mathrm{~s}$ at $72{ }^{\circ} \mathrm{C}$ with a final extension of $72{ }^{\circ} \mathrm{C}$ for $5 \mathrm{~min}$. The nucleotide sequences obtained has been deposited in the EMBL database. Search of nucleotide sequence homology was done using the Blast algorithm (Altschul et al., 1990) and then the sequences were aligned using ClustalW (Thompson $\boldsymbol{e t}$ al., 1994). Phylogenetic analysis was performed using MEGA software (Tamura et al., 2013). The evolutionary distances were computed using the Maximum Composite Likelihood method (Tamura et al., 2004).

\section{Purification of bacteriocin}

\section{Ammonium sulfate precipitation}

For the isolation of bacteriocin, the bacterial strain was propagated in MRS broth at $37{ }^{\circ} \mathrm{C}$ for $24 \mathrm{~h}$. The cells were removed by centrifugation at $10,000 \mathrm{rpm}$, for 30 min at $4{ }^{\circ} \mathrm{C}$ and the cell free supernatant was collected. The supernatant fluid was then precipitated with ammonium sulphate of $10 \%, 20 \%, 30 \%, 40 \%, 50 \%$ and $60 \%$ saturation for overnight at $4{ }^{\circ} \mathrm{C}$ with gentle stirring till the level of saturation occurs (Harris $\boldsymbol{e t}$ al., 1989). A floating precipitate was formed. After centrifugation the precipitate was resuspended in $25 \mathrm{ml}$ of potassium phosphate buffer $(\mathrm{pH} 6.0)$. The protein precipitate was concentrated and dialyzed in a tubular cut-off membrane, against buffer for $24 \mathrm{~h}$. The obtained dialysate was used as partially purified sample.

\section{Sepharose column chromatography}

The partially purified bacteriocin was further purified by conventional gel filtration chromatography using sepharose G-50 column, (De courcy, 2004). The dialysed sample was injected into a sepharose fast-flow column which was preequilibrated with $20 \mathrm{mM}$ sodium phosphate buffer $(\mathrm{pH} \mathrm{6.8)}$. The absorbed bacteriocin was eluted with phosphate buffer at a flow rate of $0.5 \mathrm{ml} / \mathrm{min}$ for 24 h. Each fraction was carried out for antimicrobial activity using Staphylococcus aureus, Enterococcus faecalis, Proteus mirabilis, Salmonella typhi and Escherichia coli as indicator strains. The fractions with high antimicrobial activity were pooled and the concentrated fraction further purified by HPLC.

\section{HPLC}

The final purification step was performed with HPLC run. Bioactive fraction F2 obtained from column chromatography was subjected to high performance liquid chromatography (Guyonnet et al., 2000). The sample was slowly injected into the HPLC system and it was passed through the C18 column. Hexane and ethyl acetate was used as mobile phase and the bacteriocin was eluted at the flow rate of $1 \mathrm{ml}$ min -1 . The absorption was measured at $220 \mathrm{~nm}$.

\section{RESULTS}

\section{Isolation and screening of Lactobacillus strains for probiotic properties}

About 32 isolates of Lactobacillus spp. were isolated from home made curd and were characterised as non-motile, catalase negative, Gram positive rods. All the thirty two strains were evaluated for their probiotic properties of acid, thermo, bile, osmo tolerance, in vitro antimicrobial activity and antibiotic susceptibility.

\section{Acid tolerance}

Tolerance level of all Lactobacillus spp to acidic environment was found significantly variable. The growth pattern and the survival rate of the

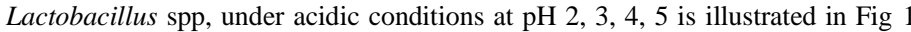
(a) and (b). All the thirty two strains had shown limited growth towards acidic conditions at $\mathrm{pH}$ 4. Maximum growth of $1.82 \mathrm{O} . \mathrm{D}$ was recorded for $\mathrm{L}_{2}$ strain of Lactobacillus at $\mathrm{pH}$ value 4.0 , followed by $\mathrm{L}_{3}(1.63), \mathrm{L}_{1}(1.27), \mathrm{L}_{6}(1.44), \mathrm{L}_{8}(0.78)$ and $\mathrm{L}_{9}(0.90)$ isolates, the remaining Lactobacillus isolates shown fair growth. The decline in the growth was noticed at $\mathrm{pH} 2.0$ and 3.0. the maximum growth of 1.72 O.D value at $\mathrm{pH} 4$ and the lowest growth of 0.78 at $\mathrm{pH} 3$ was obtained to the reference strain. As shown in fig 1 (a), as the $\mathrm{pH}$ value increases beyond 4 growth of all the cultures decreased correspondingly. Regarding the cell viability, highest viable count of $127 \mathrm{CFU} / \mathrm{ml}$ at $\mathrm{pH} 4.0$ was found with Lactobacillus spp of $\mathrm{L}_{2}$ followed by Lactobacillus spp of $\mathrm{L}_{5}, \mathrm{~L}_{3}, \mathrm{~L}_{6}, \mathrm{~L}_{1}$ and $\mathrm{L}_{4}$ and the number of viable cells of these Lactobacillus spp reduced at $\mathrm{pH}$ value 5.0 The Lactobacillus spp $\mathrm{L}_{2}$ was found to survive well at $\mathrm{pH} 4$ followed by decrease in the number of viable cells at $\mathrm{pH} 5.0$ 


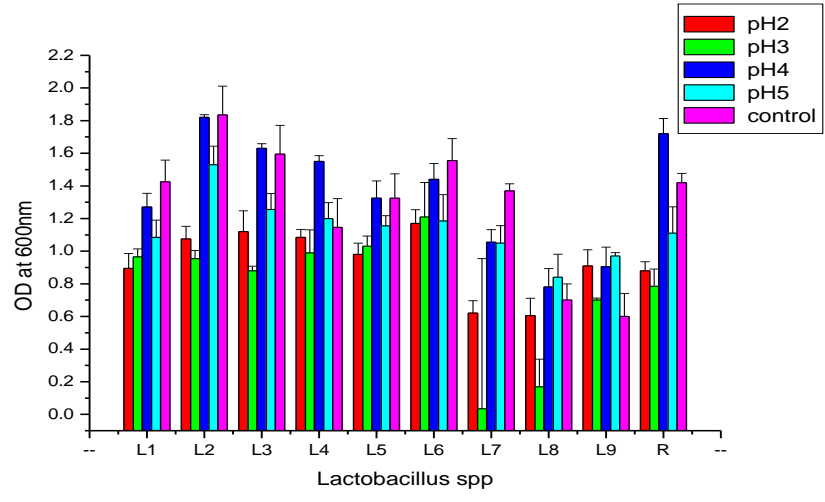

(a)

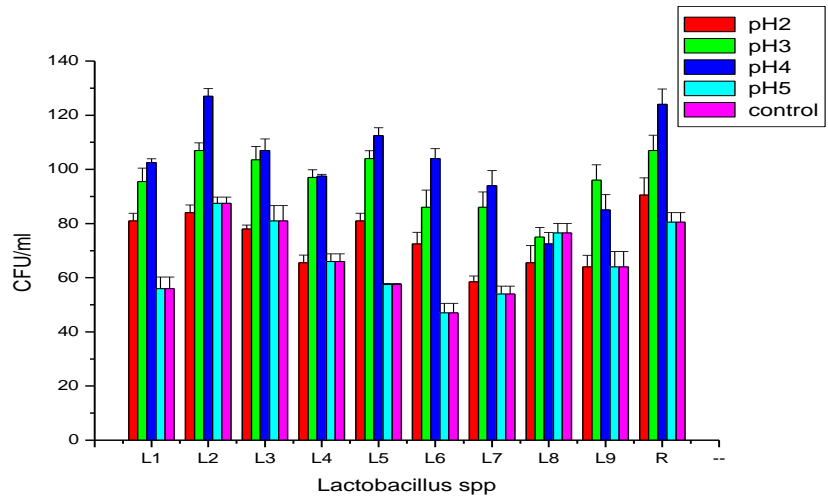

(b)

Figure 1 (a) Growth of Lactobacillus spp in acidic pH , (b)Viable count of Lactobacillus spp in acidic $\mathrm{pH}$

\section{Thermo tolerance}

All the isolated Lactobacillus spp shown moderate growth and cell viability at $40^{\circ} \mathrm{C}$, but the Lactobacillus spp of $\mathrm{L}_{2}$ yielded maximum growth of $1.8 \mathrm{OD}$, with the viable count of $114 \mathrm{CFU} / \mathrm{ml}$ at $40^{\circ} \mathrm{C}$, followed by other isolates $\mathrm{L}_{1}(1.57)$, $\mathrm{L}_{3}(1.59), \mathrm{L}_{4}(1.68), \mathrm{L}_{5}(1.56), \mathrm{L}_{6}(1.43)$ and $\mathrm{L}_{7}(1.07)$. The Lactobacillus spp $\mathrm{L}_{2}$ was still resistant at $50{ }^{\circ} \mathrm{C}$ with 0.38 O.D value and $40 \mathrm{CFU} / \mathrm{ml}$ and it rapidly lost the growth at $60{ }^{\circ} \mathrm{C}$. The remaining Lactobacillus spp shown fair growth at $50{ }^{\circ} \mathrm{C}$. Figure 2 (a) and (b) represent the growth rate and viable count of Lactobacillus spp at different temperatures. The above results revealed that the nine Lactobacillus strains of $\mathrm{L}_{1}$ to $\mathrm{L}_{9}$ are found to be tolerant to $50{ }^{\circ} \mathrm{C}$ temperature with good growth and cell viability. There is gradual decrease in the growth as the temperature increased.

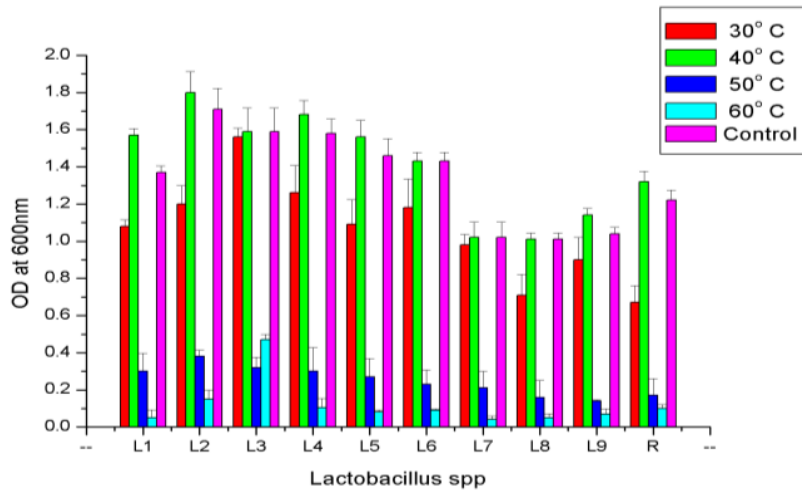

(a)

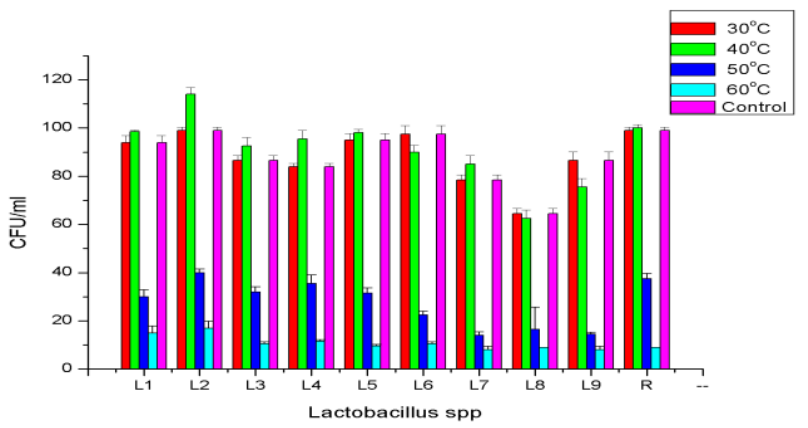

(b)

Figure 2 (a) Growth of Lactobacillus spp at different temperatures, (b) Viable count of Lactobacillus spp at different temperatures

\section{Bile tolerance}

Effect of bile salt on the isolated Lactobacillus spp at different concentrations (sodium thioglycolate) was evaluated (Fig 3 (a) and (b)). Maximum growth of $1.82 \mathrm{OD}$ value was obtained for Lactobacillus $\mathrm{spp}$ of $\mathrm{L}_{2}$, followed by the isolates of $\mathrm{L}_{3}, \mathrm{~L}_{4}$ and $\mathrm{L}_{6}$ with the $\mathrm{OD}$ values of $1.63,1.55$ and 1.44 respectively at $2 \%$ level of bile concentration. The highest viable count of $84 \mathrm{CFU} / \mathrm{ml}$ was found with Lactobacillus spp $\mathrm{L}_{2}$ and $\mathrm{L}_{3}$ at $2 \%$ bile concentration followed by Lactobacillus spp of $\mathrm{L}_{1}, \mathrm{~L}_{6}, \mathrm{~L}_{8}$ and $\mathrm{L}_{4}$. The growth and the viable counts of Lactobacillus spp $\mathrm{L}_{3}, \mathrm{~L}_{4}, \mathrm{~L}_{8}$ and $\mathrm{L}_{6}$ was decreased as the bile salt concentration increased to $3 \%$ or decreased to $1 \%$.

\section{Osmo tolerance}

Tolerance to salt concentration was tested as an additional indicator for survival of the bacterial strain. The Lactobacillus spp $\mathrm{L}_{2}$ exhibited maximum growth at 2 $\% \mathrm{NaCl}$ concentration with 1.93 O.D value, whereas the isolates of $\mathrm{L}_{3}, \mathrm{~L}_{4}, \mathrm{~L}_{5}$ and $\mathrm{L}_{6}$ shown $1.59,1.14,1.32$ and 1.55 O.D values respectively when compared to the other isolates. The results are shown in fig 4 (a) and (b). Further the growth and the viable count started to decline significantly at $2.5 \%$ and $3.0 \%$ concentration of $\mathrm{NaCl}$ with Lactobacillus spp $\mathrm{L}_{2}$ isolate. The results indicates that all the five tested concentrations of salt influenced the growth and viability of Lactobacillus isolates $\mathrm{L}_{11}$ to $\mathrm{L}_{32}$. The viable count of the Lactobacillus spp $\mathrm{L}_{2}$ was found to be greater at $2 \% \mathrm{NaCl}$ concentration of $104 \mathrm{CFU} / \mathrm{ml}$ followed by $\mathrm{L}_{3}, \mathrm{~L}_{1}$ and $\mathrm{L}_{5}$ isolates. The results clearly indicates that the strain $\mathrm{L}_{2}$ has maximum tolerance to $2 \% \mathrm{NaCl}$ concentration followed by $\mathrm{L}_{4}, \mathrm{~L}_{3}, \mathrm{~L}_{5}, \mathrm{~L}_{6}$ and $\mathrm{L}_{9}$.

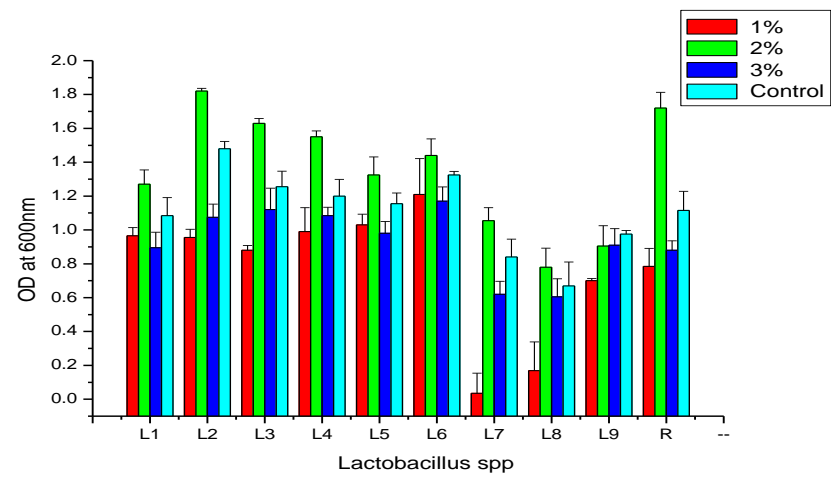

(a)

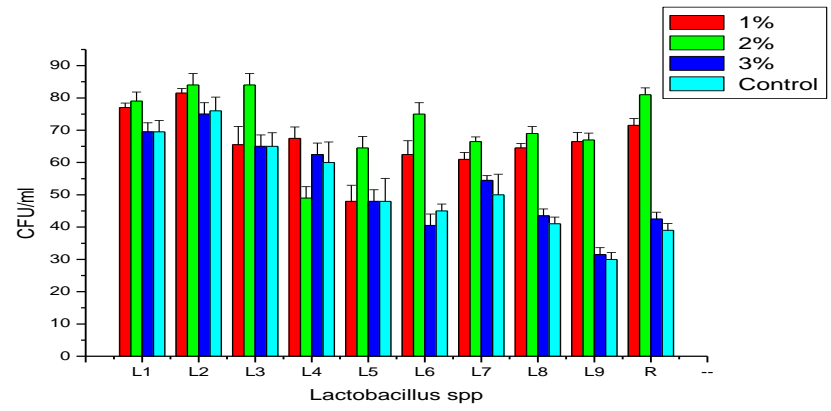

(b)

Figure 3 (a) Growth of Lactobacillus spp in bile salt, (b) Viable count of Lactobacillus spp in bile salt 

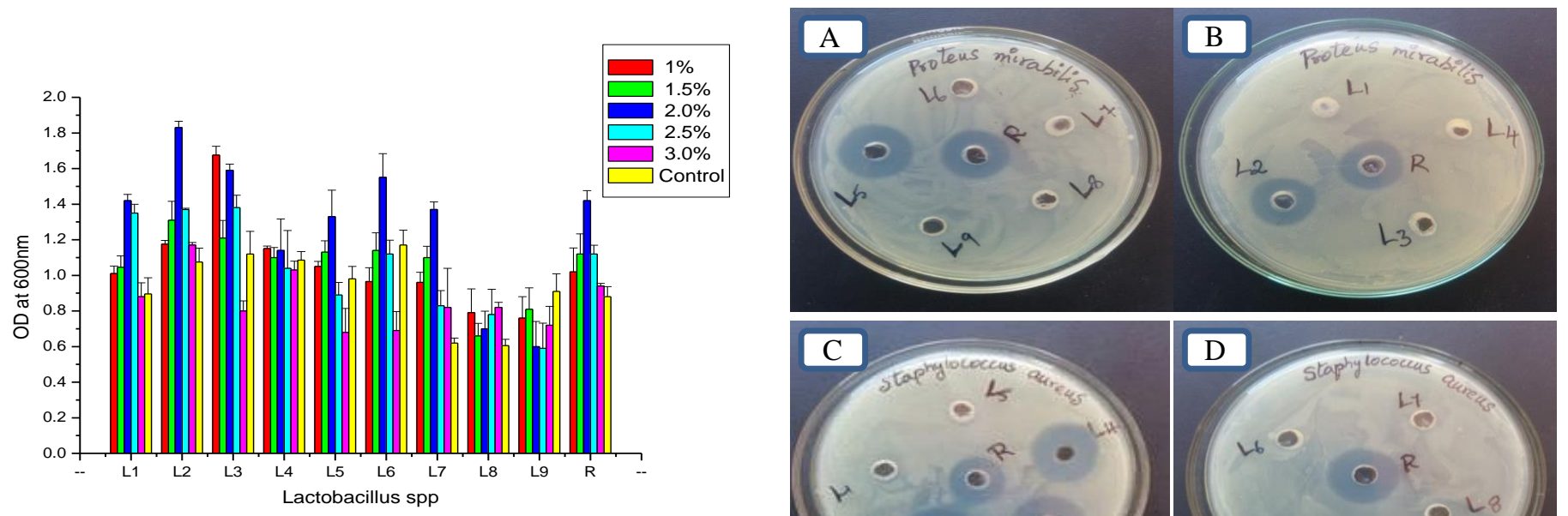

(a)

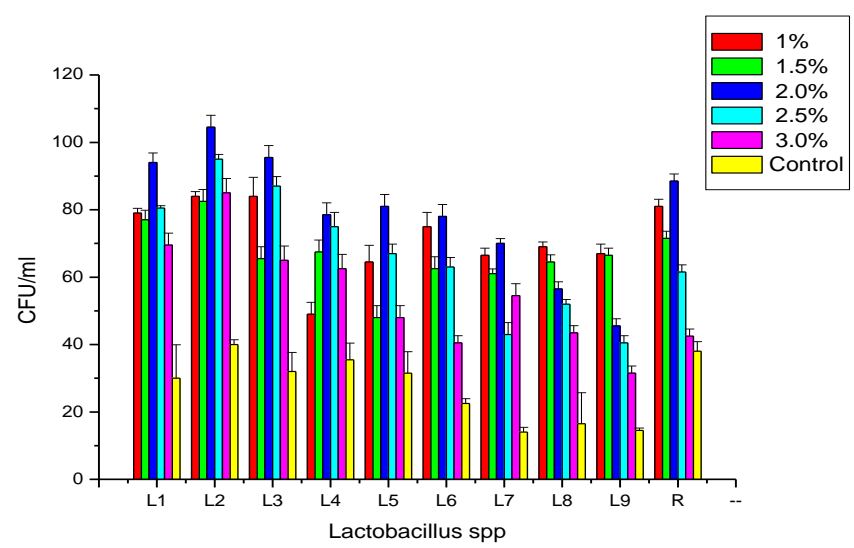

(b)

Figure 4 (a) Growth of Lactobacillus spp in different $\mathrm{NaCl}$ concentration,

Viable count of Lactobacillus spp in different $\mathrm{NaCl}$ concentration

(b)

\section{Screening of Lactobacillus isolates for bacterial activity}

The selected nine Lactobacillus isolates having probiotic properties were able to inhibit the growth of some enteropathogenic organisms by agar well diffusion assay (Fig 5 A-K). To study the antimicrobial properties of bacteriocin the $\mathrm{pH}$ of the cell free supernatant (CFS) of the nine Lactobacillus strains was neutralized with $1 \mathrm{~N} \mathrm{NaOH}$ solution in order to eliminate acids like lactic acid and then sterilized by boiling. The CFS was treated with catalase of $5 \mathrm{mg} / \mathrm{ml}$ to completely eliminate possible inhibitory effect of hydrogen peroxide. Inhibitory activity of the neutralized cell free supernatant of Lactobacillus spp $\mathrm{L}_{2}$ was able to inhibit the growth of Salmonella typhimurium, Escherichia coli, Staphylococcus aureus, Enterococcus faecalis and Proteus mirabilis, the antimicrobial activity of CFS of Lactobacillus spp $\mathrm{L}_{3}$ could inhibit the growth of Staphylococcus aureus and Escherichia coli, and Lactobacillus spp $\mathrm{L}_{4}$ has the ability to inhibit Staphylococcus aureus, whereas the Lactobacillus spp $\mathrm{L}_{5}$ inhibit Proteus mirabilis, Escherichia coli and Salmonella typhimurium, Lactobacillus spp $\mathrm{L}_{6}$ possess antimicrobial activity against Salmonella typhimurium, while Lactobacillus spp $\mathrm{L}_{1}, \mathrm{~L}_{7}, \mathrm{~L}_{8}$ and $\mathrm{L}_{9}$ did not show any antimicrobial activity against the enteropathogens. The results are presented in (Tab1). Bacteriocin capable of inhibiting the growth of gram negative strains is very obscure; however the strain $\mathrm{L}_{2}$ exhibited strong antagonism to gram positive and gram negative pathogenic bacteria than the other strains. Hence strain $\mathrm{L}_{2}$ was selected
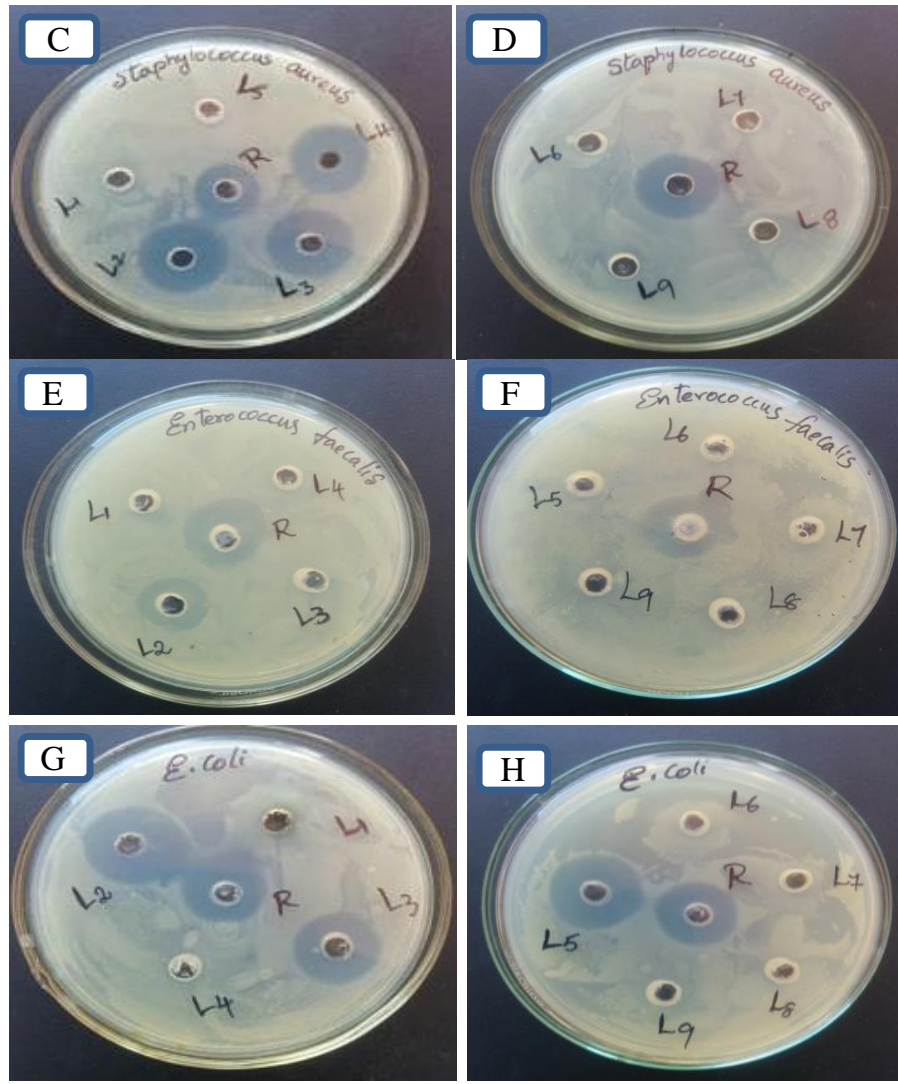

Figure 5 Screening of antimicrobial activity of selected Lactobacillus spp agains enteropathogens. $\mathrm{L}_{1}, \mathrm{~L}_{2}, \mathrm{~L}_{3}, \mathrm{~L}_{4}, \mathrm{~L}_{5}, \mathrm{~L}_{6}, \mathrm{~L}_{7}, \mathrm{~L}_{8}, \mathrm{~L}_{9}$ - Lactobacillus spp

R- Reference strain. A \& B: The Lactobacillus spp $\mathrm{L}_{2}, \mathrm{~L}_{5}$ showing inhibition zones against Proteus mirabilis; Figure C \&D: The Lactobacillus $\operatorname{spp} \mathrm{L}_{2}, \mathrm{~L}_{3}, \mathrm{~L}$ showing inhibition zones against Staphylococcus aureus: E \& F: Lactobacillus spp $\mathrm{L}_{2}$ show inhibition zones against Enterococcus faecalis; $\mathrm{G} \& \mathrm{H}-$ Lactobacillus spp $\mathrm{L}_{2}, \mathrm{~L}_{3}, \mathrm{~L}_{5}$ showing inhibition zones against Escherichia coli. I, $\mathrm{J}$ and $\mathrm{K}$ showing inhibition zone against Salmonella typhi by Lactobacillus spp $\mathrm{L}_{2}, \mathrm{~L}_{5}, \mathrm{~L}_{6}$

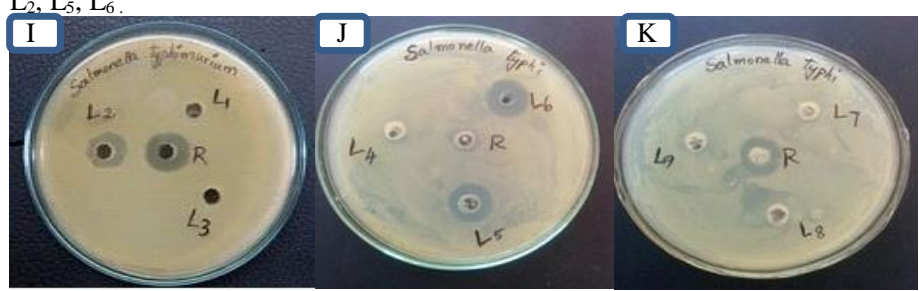

$\underline{\text { Table } 1 \text { Inhibitory activity of the isolated Lactobacillus spp }}$

\begin{tabular}{|c|c|c|c|c|c|c|c|c|c|c|}
\hline \multirow{2}{*}{$\begin{array}{l}\text { Indicator } \\
\text { strains }\end{array}$} & \multicolumn{9}{|c|}{ Lactobacillus spp } & \multirow[b]{2}{*}{$\mathbf{R}$} \\
\hline & $\mathbf{L}_{1}$ & $\mathbf{L}_{2}$ & $\mathbf{L}_{3}$ & $\mathbf{L}_{4}$ & $\mathbf{L}_{5}$ & $\mathrm{~L}_{6}$ & $\mathbf{L}_{7}$ & $\mathbf{L}_{8}$ & $\mathbf{L}_{9}$ & \\
\hline Escherichia coli & - & + & + & - & + & - & - & - & - & + \\
\hline $\begin{array}{l}\text { Enterococus } \\
\text { faecalis }\end{array}$ & - & + & - & - & - & - & - & - & - & + \\
\hline $\begin{array}{l}\text { Pseudomonas } \\
\text { fluorescence }\end{array}$ & - & - & - & - & - & - & - & - & - & - \\
\hline $\begin{array}{l}\text { Pseudomonas } \\
\text { aerugenosa }\end{array}$ & - & - & - & - & - & - & - & - & - & - \\
\hline $\begin{array}{l}\text { Staphylococcus } \\
\text { aureus }\end{array}$ & - & + & + & + & - & - & - & - & - & + \\
\hline $\begin{array}{l}\text { Salmonella } \\
\text { typhimuriun }\end{array}$ & - & + & - & - & + & + & - & - & - & + \\
\hline $\begin{array}{l}\text { Proteus } \\
\text { mirabilis }\end{array}$ & - & + & - & - & + & - & - & - & - & + \\
\hline
\end{tabular}

Legend: - indicates no inhibition; + indicates Inhibition 


\section{Molecular identification of bacteriocinogenic Lactobacillus spp}

16S rRNA gene sequence of the selected bacteriocinogenic Lactobacillus strain $\left(\mathrm{L}_{2}\right)$ was compared with the sequence available in GenBank database (http://www.ncbi.nlm.nih.gov) using BLAST software and sequence was deposited in the NCBI GenBank. Based on the alignment results, the Lactobacillus spp $\mathrm{L}_{2}$ (KF836431) showed $99 \%$ sequence homology with Lactobacillus fermentum. The phylogenetic tree was constructed based on neighbour joining tree method as illustrated in Fig 6. The phylogenetic tree revealed that the bacterial strain is closely related to Lactobacillus fermentum.

Nucleotide sequence accession number: The 16S rRNA gene sequence of the Lactobacillus fermentum strain was submitted to GenBank and given accession no. KF836431.

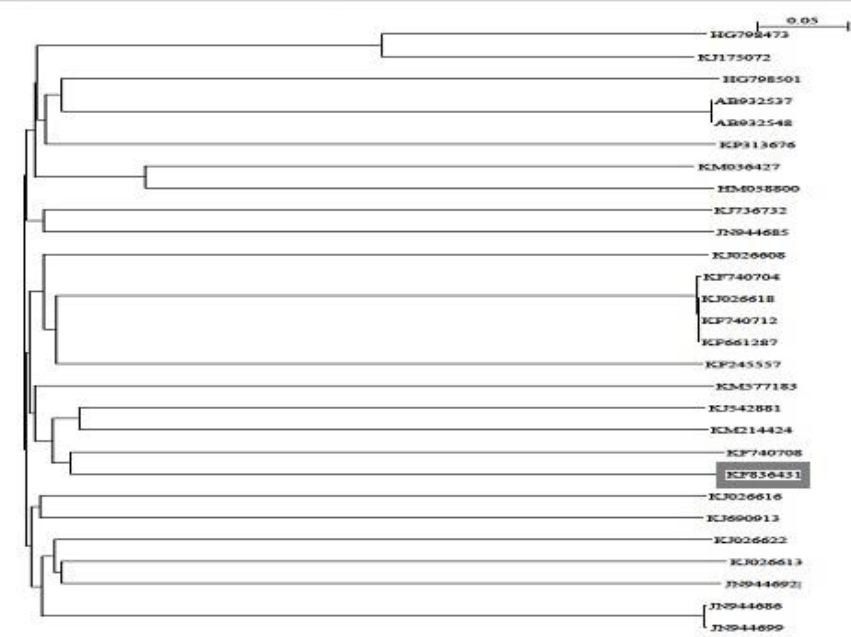

Figure 6 The phylogenetic position of the Lactobacillus fermentum strain among neighboring species

\section{Purification of bacteriocin produced by Lactobacillus fermentum}

The cell free culture supernatant was precipitated with $40 \%$ ammonium sulphate and the bacteriocin protein precipitate was collected by centrifugation and dialysed against potassium phosphate buffer for overnight and subsequently purified by conventional gel filtration chromatography using sepharose G-50 column equilibrated with sodium phosphate buffer. The bacteriocin fractions of $\mathrm{F} 1$, F2, F3, F4 and F5 were obtained by eluting with $0.05 \mathrm{M}$ sodium phosphate buffer and all the five fractions were evaluated for their antibacterial activity agains indicator strains Staphylococcus aureus, Enterococcus faecalis, Proteus mirabilis, Salmonella typhi and Escherichia coli. The highest bacteriocin activity was observed with F2 fraction of 6400 AU/ml for Staphylococcus aureus, 3200 AU/m for Enterococcus faecalis, $1600 \mathrm{AU} / \mathrm{ml}$ for Proteus mirabilis, $8100 \mathrm{AU} / \mathrm{ml}$ for Salmonella typhi and $2700 \mathrm{AU} / \mathrm{ml}$ for Escherichia coli (Tab 2). The bioactive fraction F2 with highest antimicrobial activity was further purified by HPLC analysis.

\section{HPLC}

The chromatogram of bacteriocin produced by Lactobacillus fermentum revealed an active peak at the retention time of 2.73 minutes as shown in Fig 7.The standard bacteriocin used as a reference sample for this study also revealed a single active peak at a retention time of 2.73 minutes (Fig 8). The efficiency of the bacteriocin purification steps were presented in (Tab 3). The recovery yield of bacteriocin by ammonium sulphate precipitation was about $75.5 \%$ and the total activity was approximately $1600 \mathrm{AU} / \mathrm{ml}$ and the purification reached to 1.16 folds. The total activity of bacteriocin after gel filtration and HPLC was 900 $\mathrm{AU} / \mathrm{ml}$ and $300 \mathrm{AU} / \mathrm{ml}$. The purification increased to 5.68 and 10.44 folds respectively by gel filtration and HPLC, but the yield recovery is only $29.5 \%$ and $14 \%$

Table 2 Antimicrobial activity (AU/ml) of sepharose column eluted fractions of F1 to F5

\begin{tabular}{lccccc}
\hline & \multicolumn{4}{c}{ Antimicrobial activity (AU/ml) } \\
\hline $\begin{array}{l}\text { Number of } \\
\text { Fractions }\end{array}$ & Staphylococcus aureus & Enterococcus faecalis & Proteus mirabilis & Salmonella typhi & \multirow{2}{*}{ Escherichia coli } \\
\hline 1 & 200 & 400 & 200 & 400 & 300 \\
\hline 2 & 6400 & 3200 & 1600 & 8100 & 2700 \\
\hline 3 & 800 & 400 & 800 & 300 & 300 \\
\hline 4 & 1600 & 800 & 400 & 300 & 300 \\
\hline 5 & 300 & 300 & 400 & 300 \\
\hline
\end{tabular}

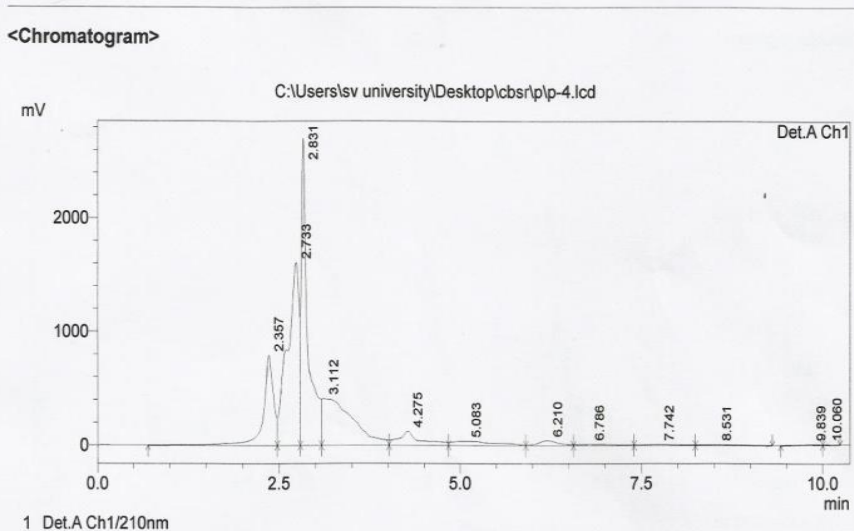

Figure 7 HPLC chromatogram of the purified active fraction of bacteriocin

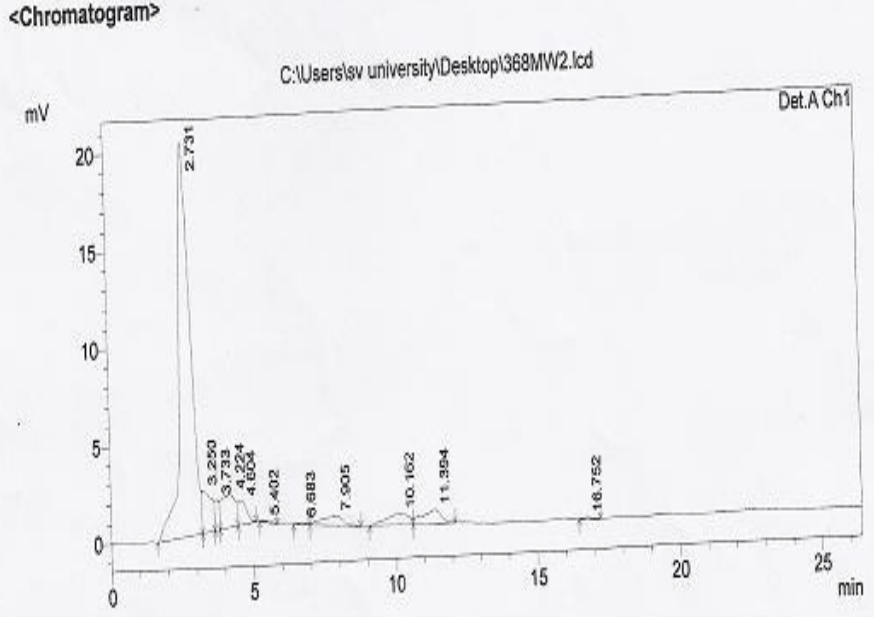

Figure 8 HPLC chromatogram of the standard bacteriocin

Table 3 Steps involved in purification of bacteriocin from Lactobacillus fermentum

\begin{tabular}{|c|c|c|c|c|c|c|}
\hline Purification Stage & $\begin{array}{l}\text { Volume } \\
\text { (ml) }\end{array}$ & $\begin{array}{c}\text { Protein } \\
\text { concentration } \\
(\mathrm{mg} / \mathrm{ml})\end{array}$ & $\begin{array}{l}\text { Total activity } \\
(\text { AU /ml) }\end{array}$ & Purification & Fold & Recovery \\
\hline Culture supernatant & 100 & 0.32 & 2700 & 0.0 & & 100 \\
\hline $\begin{array}{l}\text { Ammonium sulphate } \\
\text { precipitation }\end{array}$ & 10 & 0.15 & 1600 & 1.16 & & 75.5 \\
\hline $\begin{array}{l}\text { Column } \\
\text { chromatography }\end{array}$ & 5 & 0.0214 & 900 & 5.68 & & 29.5 \\
\hline HPLC chromatography & 1 & 0.012 & 300 & 10.44 & & 14 \\
\hline
\end{tabular}




\section{DISCUSSION}

The beneficial effects of live bacteria like probiotics, on human health are increasingly being promoted during the last few years. Most probiotics are Lactic Acid Bateria isolated from the dairy products. According to the FAO/WHO guidelines (Joint FAO/WHO, 2002), prospective probiotics must fulfil certain criteria and should be selected through a defined process. The selection criteria for LAB to be used as 'probiotics' in food, include the ability to produce antimicrobial substances towards pathogens, withstand transit through the gastrointestinal tract, modulate immune responses association with health benefits. In this investigation, we have carried out the identification and evaluation of probiotic potential of the Lactobacillus strains isolated from home made curd, characterization of bacteriocinogenic Lactobacillus strain and also purification of the antimicrobial compound produced by a naturally fermented curd isolate of lactic acid bacteria, Lactobacillus fermentum.

About 32 isolated strains of Lactobacillus spp were screened for the probiotic properties such as acid, thermo, bile and osmo tolerance. All the thirty two strains showed moderate to good tolerance towards acid, thermo, bile and osmo conditions. Results revealed that maximum growth was recorded in case of Lactobacillus spp $\mathrm{L}_{2}$ (Lactobacillus fermentum) at $\mathrm{pH}$ 4.0, whereas least growth was investigated in Lactobacillus spp $\mathrm{L}_{8}$ and $\mathrm{L}_{9}$. Martini et al., (1987) also reported that the tolerance at $\mathrm{pH} 4$ is significant as ingestion with food or dairy products raise the $\mathrm{pH}$ in stomach to 4 or higher. The Lactobacillus spp $\mathrm{L}_{2}$ shown greater viable count at $\mathrm{pH} 4.0$ followed by Lactobacillus spp of $\mathrm{L}_{5}, \mathrm{~L}_{3}, \mathrm{~L}_{6}, \mathrm{~L}_{1}$ and $\mathrm{L}_{4}$ and the number of viable cells of these Lactobacillus spp decreased at $\mathrm{pH} 5.0$ All the Lactobacillus spp shown moderate growth at $40^{\circ} \mathrm{C}$, but the Lactobacillus spp $\mathrm{L}_{2}$ exhibited highest growth and viable count at $40^{\circ} \mathrm{C}$, followed by other isolates $\mathrm{L}_{1}, \mathrm{~L}_{3}, \mathrm{~L}_{4}, \mathrm{~L}_{5}, \mathrm{~L}_{6}$ and $\mathrm{L}_{7}$. Temmerman et al., (2001) also reported the highest viable count of the bacteria, in dried probiotic supplements tested. The effect of bile salts on the survivability of different Lactobacillus strains depends on the concentration and the specific properties of the strains. It is well known that bile-salt concentration in the gut is not static, ranging from $1.5 \%$ to $2 \%(\mathrm{w} / \mathrm{v})$ in the first hour of digestion, and decrease afterwards to around $0.3 \%(\mathrm{w} / \mathrm{v})$ (Noriega et al., 2004). In this study, we used 1\%, 2\% and 3\% of sodium thioglycolate to study the bile tolerance of Lactobacillus strains. Similar studies have been used by other researchers (Brashears et al., 2003). According to our findings, Lactobacillus fermentum $\mathrm{L}_{2}$ showed a strong bile tolerance with maximum growth and highest viable count at $2 \%$ bile concentration. Since bile salts disorganize the structure of the cell membrane, it is toxic for living cells (Margolles et al., 2003). Therefore, bile tolerance is considered as an importan characteristic of the Lactobacillus which enables it to survive, grow and exert its action in gastrointestinal transit. Lactobacillus strains which could grow and metabolize in normal physical bile concentration could survive in gastrointestine. $\mathrm{NaCl}$ is an inhibitory substance which antagonizes the growth of certain types of bacteria, interestingly in our study the Lactobacillus spp of $\mathrm{L}_{2}$ shown tolerance at $2 \% \mathrm{NaCl}$ concentration with an viable count of $104 \mathrm{CFU} / \mathrm{ml}$. Elizete and Carlos, (2005) isolated lactobacilli from gastrointestinal tract of swine were tolerable to $4-8 \% \mathrm{NaCl}$. Veera jothi et al., (2012) also reported the tolerance of Lactobacillus VJ 15 and VJ32 at $2 \% \mathrm{NaCl}$ concentration in the medium. In our study out of 32 Lactobacillus spp isolated, only nine strains of $\mathrm{L}_{1}, \mathrm{~L}_{2}, \mathrm{~L}_{3}, \mathrm{~L}_{4}, \mathrm{~L}_{5}$ $\mathrm{L}_{6}, \mathrm{~L}_{7}, \mathrm{~L}_{8}$ and $\mathrm{L}_{9}$ possessing excellent acid, thermo, bile and osmo tolerance were selected for the screening of their antimicrobial activity towards a broad range of target microorganisms. Interestingly, $\mathrm{L}_{2}$ strain showed strong inhibition against Salmonella typhimurium, Escherichia coli, Staphylococcus aureus, Enterococcus faecalis and Proteus mirabilis. This strain was further identified as Lactobacillus fermentum by $16 \mathrm{~S}$ rRNA analysis. De Vuyst et al., (1996) also reported that many proteinaceous antibacterial compounds from Lactobacillus amylovorus showed stimulation and broad inhibitory spectra, against Gram-positive and Gram-negative bacteria. These findings are consistent with those of the present study. The production of bacteriocins by such strains can provide additiona benefits concerning their application in the food industry. The inhibitory activity of Lactobacillus fermentum against different enteropathogens is a feature of interest for further investigation. This extends the investigation further into the characterization of the isolate $\left(\mathrm{L}_{2}\right)$ and purification of the bacteriocin produced by this isolate.

The utilization of bacteriocins or bacteriocin-producing bacteria in livestock is a field with enormous possibilities for both research and commercialization. We can easily say that there has been very limited research in this area, but in recent years the number of investigators has dramatically increased. As more countries develop antibiotic-limiting policies, the need for alternative antimicrobial will probably be the main driving force to continue identifying novel bacteriocins and testing existing ones. Because of the relative specificity of bacteriocins as compared with antibiotics, it can be anticipated that the identification of broader spectrum bacteriocins will be active research endeavour.

The 16S rRNA gene sequencing has been performed for the selected potential bacteriocinogenic Lactobacillus spp $\left(\mathrm{L}_{2}\right)$. The PCR product was sequenced and subjected to nucleotide BLAST. Dickson et al., (2005) used a novel species specific PCR assay for identifying Lactobacillus fermentum. It would be desirable to construct a phylogenetic tree using $16 \mathrm{~S}$ rRNA data and compare it with the BLAST sequences. There are reports identifying Lactobacillus strains by oligonucleotide probes or PCR assays (Ward 1999; Schleifer et al., 1995).

Since bacteriocins are secreted into the culture medium, most strategies start with a step to concentrate bacteriocins from the culture free supernatant, using ammonium sulfate precipitation (Yang et al., 1992). In our study, we have purified bacteriocin from the cell free supernatant of Lactobacillus fermentum ( $\mathrm{L}_{2}$ strain) by three-step protocol, using ammonium sulphate precipitation (40\% w/v), sepharose G-50 column chromatography and HPLC (Tiwari and Srivastava, 2008 b). In the initial step of purification, the cells were removed from the culture broth by centrifugation. The cell free supernatant was concentrated by ammonium sulphate precipitation, where the bacteriocin was concentrated at $40 \%$ saturation and then the filtrate was dialyzed, pooled and concentrated for further purification, the partially purified dialysate was applied on sepharose G- 50 column chromatography and the fractions obtained (F1 - F5) were assayed for antibacterial activity. The active fraction F2 obtained in gel filtration chromatography was found to be effective with highest antimicrobial activity against the pathogens Staphylococcus aureus, Enterococcus faecalis, Proteus mirabilis, Salmonella typhi and Escherichia coli. The bioactive fraction F2 was further subjected to HPLC chromatography and has been successful in the purification of bacteriocin from Lactobacillus fermentum $\left(\mathrm{L}_{2}\right.$ strain). Gong $\boldsymbol{e}$ al.,(2010) and Meizhong Hu et al., (2013) also employed these techniques for the purification of plantaricin 163, plantaricin MG. HPLC results revealed a single peak eluted at 2.73 minutes at $220 \mathrm{~nm}$. The recovery (\% yield) of bacteriocin was decreased particularly in HPLC. Similar results were reported by many authors that high loss of bacteriocin occurs during purification processes (BogovicMatijasic and Rogels, 1998). The bacteriocin purified from Lactobacillus fermentum showing strong antagonistic effect against the enteropathogens indicated its usefulness in the preservation of different food products enhancing their shelf life.

Probiotic properties and bacteriocin production are two of the several selection criteria that must be met by probiotics (Corr et al., 2007). Diseases associated with enteropathogens such as intestinal abscesses and acute diarrhoeal diseases are rarely reported. In contrast, our strain might be proven to be beneficial as intestinal LAB and possibly also as probiotics; however further research is necessary to confirm whether bacteriocins from probiotic lactic acid bacteria are among the compounds responsible for inactivation of pathogens in urogenital tracts.

These attempts were thus expected to select a promising isolate of Lactobacillus possessing better probiotic potential as well as elucidation of good bacteriocin activity and production. This may further useful in the preservation of different food products enhancing their shelf life and also these biomolecules can be applied as biopreservatives, as nutraceuticals as well as for therapeutics in treating gastro intestinal diseases.

\section{CONCLUSION}

The results of the present study clearly suggest that the bacteriocin producing Lactobacillus fermentum with probiotic properties could potentially used in biopreservation of food as well as probiotic compounds. The studies on Lactobacillus fermentum deserve further investigation to elucidate its potential health benefits. However, there is still a long way to go for this strain to work as a probiotic for industry. In this regard, many efforts will be done to develop new scaffolds for effective antimicrobial peptides from natural product biosynthetic pathway.

Acknowledgements: The author Dr. N.S. Meera is grateful acknowledge to thank UGC PDF, New Delhi for financial assistance under the scheme SC/ST Post Doctoral Fellowship for the year 2017-18. Ref. No. F./31-1/2017/PDFSS2017-18-AND-14173

\section{REFERENCES}

Altschul, SF., Gisn, W., Miller, W., Myers, EW., Lipman, D.J. (1990). Basic Local Alignment Search Tool. Journal of Molecular Biology 215, 403-410. https://doi.org/10.1016/S0022-2836(05) 80360-2

Amann, RI., Ludwig, W., Schleifer, K.H. (1995). Phylogenetic identification and in situ detection of individual microbial cells without cultivation. Microbiological Reviews. 59, 143-169. http//mmbr.asm.org/content/59/1/143

Andrighetto, C., Dedea, P., Lombardi, A., Neviani, E., Rossetti, L., Giraffa, G (1998). Molecular identification and cluster analysis of homofermentative thermophilic lactobacilli isolated from dairy products. Research in Microbiology. 149, 631-643. https://doi.org/10.1016/S0923-2508(99)80011-4

Axelsson, L. (1998). Lactic acid bacteria: classification and physiology. In: Lactic Acid Bacteria: Microbiology and Functional Aspects, 2nd edition. eds. Salminen, S and von Wright, A. pp. 1- 72. Marcel Dekker, Inc. New York https://doi.org/10.1201/9780824752033.ch1

Bogovic matijasic, B., Rogels, I. (1998). Bacteriocins of Lactobacillus LF221 strain Science Symp. 'Animal Microbiology’, May 29, Domzale, Slovenia.

Brashears , M.M., Jaroni, D., Trimble, J. ( 2003). Isolation, selection and characterization of lactic acid bacteria for a competitive exclusion product to reduce 
shedding of Escherichia coli O157:H7in cattle. Journal of Food Protection. 66, 355363. https://doi.org/10.4315/0362-028X-66.3.355

Burton, JP., Cadieux, P., Reid, G. (2003). Improved understanding of the bacterial vaginal microbiota of women before and after probiotic instillation Applied Environmental Microbiology. 69, 97-101. https://doi: 10.1128/AEM.69.1.97-101.2003

Chen, H., Hoover, D.G. (2003). Bacteriocins and their food applications. Comprehensive Reviews in Food Science and Food Society. 2, 92-100. https://doi.org/10.1111/j.1541-4337.2003.tb00016.x

Chesson, A., Franklin, A., Aumaitre, A., Skold, O., Leclercq, R., Von wright, A., Guillot, J.F. (2002). Opinion of the scientific committee on animal nutrition on the criteria for assessing the safety of microorganisms resistant to antibiotics of human and veterinary importance. Directorate C - Scientific Opinions. European Commission Health and Consumer Protection Directorate-General, Brussels, Belgium.

Conway, P.L., Gorbach, S.L., Goldin, B.R .(1987). Survival of lactic acid bacteria in the human stomach and adhesion to intestinal cells. Journal of dairy Science. 70, 112. https://doi.org/10.3168/jds.S0022-0302(87)79974-3

Corr, SC., Yin, L., Christiane, U.R., Colin, H., Paul, W.T., Cormac, G.M.G (2007). Bacteriocin production as a mechanism for the anti infective activity of Lactobacillus salivarius UCC118. Proceedings of the National. Academy Sciences of the United States America. 104, 76177621. https://doi.org/10.1073/pnas.0700440104

DE Courcy, K. (2004). Column chromatography information manual. Fralin Biotechnology center. Virginia technol. pp 5-17.

DE Man, J.D., Rogosa, M., Sharpe, M.E. (1960). A medium for the cultivation of Lactobacilli. Journal of Applied Microbiology. 23, 130-135. https://doi.org/10.1111/j.1365-2672.1960.tb00188.x

DE Vuyst, L., Callewaert, R., Crabbe, K. (1996). Primary metabolite kinetics of bacteriocin biosynthesis by Lactobacillus amylovorus and evidence for stimulation of bacteriocin production under unfavourable growth conditions. Microbiology 142 817- 827. https://dx.doi.org/10.1099/00221287-142-4-817

Deegan., L.H, Cotter., P.D, Hil.,L. C, ROSS., P. (2006). Bacteriocins: Biological tools for biopreservation and shelf-life extension. International Dairy Journal. 16, 10581071. https://doi.org/10.1016/j.idairyj.2005.10.026

Del piano, M., Morelli, L., Strozzi, G.P., Allesina, S., Barba, M., Deidda, F. (2006). Probiotics: from research to consumer. Digestive and Liver Diseases 38, 248-255. https://doi.org/ 10.1016/S1590-8658(07)60004-8

Deraz., S.F, Karlsson., E.N, Hedstrom., M, Andersson., M.M, Mattiasson., B. (2005). Purification and characterisation of acidocin D20079, a bacteriocin produced by Lactobacillus acidophilus DSM 20079. Journal of Biotechnology. 117, 343-54. https://doi.org/10.1016/j.jbiotec.2005.02.005

Dickson, MP., Riggio AND, L., Macpherso, N. (2005). A novel species specific PCR assay for identifying Lactobacillus fermentum. Journal of medical Microbiology. 299-303. https://doi: 10.1099/jmm.0.45770-0

Elizete, D.F.R.P., Carlos, RS. (2005). Biochemical characterization and identification of probiotic lactobacillus for swine. Digital library of journals. B.CEPPA. Curitiba 23, 299-310. http://dx.doi.org/10.5380/cep.v23i2.4485

Erkkila, S., Petaja E. (2000). Screening of commercial meat starter cultures at low $\mathrm{pH}$ and in the presence of bile salts for potential probiotic use. Meat Science 55, 297-300. https://doi.org/10.1016/S0309-1740(99)00156-4.

Gong, H.S., Meng, X.C., Wang, H. (2010). Plantaricin MG active against Gramnegative bacteria produced by Lactobacillus plantarum KLDS1.0391 isolated from "Jiaoke", a traditional fermented cream from China. Food Control.21, 89-96. https://doi.org/10.1021/jf403370y

Guyonne, T.D., Fremaux, C., Cenatiempo, Y., Berjeaud, J.M. (2000). Method for rapid purification of class IIa bacteriocins and comparison of their activities. Applied Environmental Microbiology 66, 1744-1748. https://doi.org/10.1128/aem.66.4.17441748.2000

Harris, L.J., Daeschel, M.A., Stiles, M.E., Klaenhammer, T.R. (1989). Antimicrobial activity of lactic acid bacteria against Listeria monocytogenes. Journal of Food Protection 52, 384-387. https://doi.org/10.4315/0362-028X-52.6.384

Hans.G.H.J Heilig., Zoetendal, E.G., Vaughan, E.E., Marteau, P., Akkermans, A.D.L., De vos, W.M. (2002). Molecular diversity of Lactobacillus spp. and other lactic acid bacteria in the human intestine as determined by specific amplification of 16S ribosomal DNA. Applied Environ. Microbiology 68, 114 123. https://doi: 10.1128/AEM.68.1.114-123.2002

Jamuna, M., Jeevaratnam, K. (2004). Isolation and characterization of lactobacilli from some traditional fermented foods and evaluation of the bacteriocins. The Journal of General and Applied Microbiology. 50, 79-90. https://doi.org/10.2323/jgam.50.79

Jung-min, P., Jin-ho,S., Dan-won, L., Jae-chul, S., Hyung-joo, S., Un-jae, C., Jinman, K. (2010). Identification of the lactic acid bacteria in Kimchiaccording to initial and over-ripened fermentation using PCR and 16S rRNA gene sequence analysis. Food Science and Technology. 19, 541-546. https://doi.org/10.1007/s10068-010-0075-1

Kandler, O., Weiss, N. (1986). Genus Lactobacillus Beijerinck, 1901, 212AL (Sneath, P.H.A., Mairm, N.S., Sharpe, M.E. and Holt, J.G., Eds.), Bergeys Manual of Systematic Bacteriology. 1209-1234. Williams and Wilkins, Baltimore, MD
Margolles, A., Garcia, L., Sanchez, B., Gueimonde, M., De los reyes gavilan, C. (2003). Characterization of a Bifidobacterium strain with acquired resistance to cholate A preliminary study. International Journal of Food Microbiology 82, 191-198. https://doi.org/10.1016/S0168-1605(02)00261-1

Martini, M.C., Bollweg, GL., Levitt, M.D., Savaiano, DA. (1987). Lactose digestion by yogurt beta-galactosidase: influence of $\mathrm{pH}$ and microbial cell integrity. American Journal of Clinical Nutrition.45, 432-436. https://doi.org/10.1093/ajcn/45.2.432

Meizhong, H.U., Haizhen, Z., Chong, Z., Jiansheng, Y., Zhaoxin, L.U. (2013). Purification and Characterization of Plantaricin 163, a Novel Bacteriocin Produced by Lactobacillus plantarum 163 Isolated from Traditional Chinese Fermented Vegetables. journal of agricultural and food chemistry. Journal of Agriculture and Food Chemistry. 61, 11676-11682. https://dx.doi.org/10.1021/jf403370y

Nakagawa, T., Shimada, M., Mukai, H., Asada, K., Kato, I., Fujino, K., Sato, T. (1994). Detection of alcohol-tolerant hiochi bacteria by PCR. Applied and Environmental Microbiology. 60, 637-640.

Noriega, L., Gueimonde, M., Sanchez, B., Margolle, A., DE los reyes gavilan, C. (2004). Effect of the adaptation to high bile salts concentrations on glycosidic activity, survival at low $\mathrm{pH}$ and cross resistance to bile salts in Bifidobacterium. International Journal of Food Microbiolology. 94, 79-86. https://doi.org/10.1016/j.ijfoodmicro.2004.01.003

Pal, V., Jamuna, M., Jeevaratnam, K. (2005). Isolation and characterisation of bacteriocin producing lactic acid bacteria from a South Indian special Dosa (APPAM) batter. Journal of Culture Collections.4, 53-60.

Papamanoli, E., Tzanetakis, N., Litopoulou-tzanetaki , E., Kotzekidou, P. (2003). Characterization of lactic acid bacteria isolated from a Greek dry-fermented sausage in respect of their technological and probiotic properties. Meat Science. 65, 859-867. https://doi.org/ 10.1016/S0309-1740(02)00292-9.

Park, J.M., Shin, J., Lee, D., Song, J.C., Suh, H.J., Chang, U.J., Kim, J.M (2010). Identification of the Lactic Acid Bacteria in Kimchi According to Initial and Over-ripened Fermentation Using PCR and 16S rRNA Gene Sequence Analysis. Food Science and Biotechnololgy 19, 541-546. https:// doi.org/10.1007/s10068-010-0075-1

Saavedra, L., Minahk, C., Holgado ap de, R., Sesma, F. (2004). Enhancement of the enterocin CRL35 activity by a synthetic peptide derived from the NH2-terminal sequence. Antimicrobial Agents and Chemotherapy. 48, 2778 -2781. https:// doi.org/ 10.1128/AAC.48.7.2778-2781.2004.

Schleifer, K.H., Ehrmann, M., Beimfohr, C., Brockmann, E., Ludwig, W., Amann, R. (1995). Application of molecular methods for the classification and identification of lactic acid bacteria. International Dairy Journal. 5, 1081-1094. https://doi/pdf/10.1016/j.femsle.2004.08.049.

Song, Y.L., Kato, N., Matsumiya, Y., Liu, C.X., Kato, H., Watanabe, K. (1999) Identification of and hydrogen peroxide production by fecal and vaginal lactobacilli isolated from Japanese women and newborn infants. Journal of Clinical Microbiology. 37, 3062-3064. (PMID:10449509 PMCID:PMC85459).

Subramanyam, D., Raju naidu, D.S., Rajendra, W., Lokanatha, V. (2014), Antimicrobial activity of Lactobacillus against microbial flora of cervicovaginal infections. Asian Pacific Journal of Tropical Diseases. 4, 18-24. https://doi.org/10.1016/S2222-1808(14)60307-8]

Succi, M., Tremonte, P., Reale, A., Sorrentino, E., Grazia, L., Pacifico, S., Coppola, R. (2005). Bile salt and acid tolerance of Lactobacillus rhamnosus strains isolated from Parmigiano Reggiano cheese. FEMS Microbiology Letters. 1,129-137. https://doi.org/10.1016/j.femsle.2005.01.037

Tamura, K., Peterson, D., Peterson, N., Stecher, G., Nei, M., Kumar, S. (2011) MEGA5: molecular evolutionary genetics analysis using maximum likelihood, evolutionary distance, and maximum parsimony methods. Molecular Biology and Evolution. 28, 2731-2739. https://doi.org/10.1093/molbev/msr121.

Tamura, K., Stecher, G., Peterson, D., Filipski, A., Kumar, S. (2013). MEGA6: Moleculaar Evolutionary Genetics Analysis version 6.0. Molecular Biology and Evolution..12, 2725-2729. https://doi.org/oi: 10.1093/molbev/mst197

Temmerman, R., Pot, B., Huys, G., Swings, J. (2003). Identification and antibiotic susceptibility of isolates from probiotic products. International Journal of Food Microbiology. 25, 1-10. https://doi.org/10.1016/S0168-1605(02)00162-9 Thompson, J.D., Higgins, D.G., Gibson, T.J. (1994). Clustal W: Improving the sensitivity of progressive multiple sequence alignment through sequence weighing, position-specific gap penalties and weight matrix choice. Nucleic Acids Research, 22, 4673-4680. https://doi.org/10.1093/nar/22.22.4673.

Tiwari, S.K., Srivastava, S. (2008 b). Purification and characterization of plantaricin LR14: a novel bacteriocin produced by Lactobacillus plantarum LR/14. Appl Microbiol Biot.79: 759-767. https://doi.org/10.1007/s00253-008-1482-6

Tsai, C.C, Hsih, H.Y., Chiu, H.H., Lai, Y.Y., Liu, J.H., Yu, B., Tsen, H.Y. (2005). Antagonistic activity against Salmonella infection in vitro and in vivo $s$ for two Lactobacillus strains from swine and poultry. International Journal of Food Microbiology.102, 185-94. https://doi.org/10.1016/j.ijfoodmicro.2004.12.014

Veera jothi, V., Anandapandian, K.T.K., Shankar, T. (2012). Bacteriocin production by probiotic bacteria from curd and its field application to poultry.Archives of Applied ScienceResearch. 4, 336-347.

Verthier, F., Ehrlich, S.D. (1999). Genetic diversity within Lactobacillus sakei and Lactobacillus curvatus and design of PCR primers for its detection using 
randomly amplified polymorphic DNA. International Journal of Systematic Bacteriology. 49, 997-1007. https://doi.org/10.1099/00207713-49-3-997

Walter, J., Tannock, G.W., Tilsala-timisjarvi, A., Rodtong, S., Loach, D.M. Munro, K., Alatossava, T. (2000). Detection and identification of gastrointestina Lactobacillus species by DGGE and species-specific PCR primers. Applied and Environmental Microbiology. 66, 297-303. https://doi.org/10.1128

Ward, L.J., Timmins, M.J. (1999). Differentiation of Lactobacillus casei, Lactobacillus paracasei and Lactobacillus rhamnosus by polymerase chain reaction. Letters in Applied Microbiology. 29, 90-92. https://doi.org/10.1046/j.1365-2672.1999.00586.x

Xanthopoulous., V., Litoloulou-tzanetaki., E., Tzanetakis., $\quad$ N. (2000) Characterization of Lactobacillus isolates from infant faeces as dietary adjuncts. Food Microbiology. 17, 205-215. https://doi.org/10.1006/fmic.1999.0300

Yang, R., Johnson, M.C., Ray, B. (1992). .Novel method to extract large amounts of bacteriocins from lactic acid bacteria.Applied Environmental Microbiology. 58, 33553359

Yeung, P.S., Sanders, M.E., Kitts, D.L., Cano, R., Tong, P.S. (2002). Speciesspecific identification of commercial probiotic strains. Journal of Dairy Science. 85, 1039-1051. https://doi.org/10.3168/jds.S0022-0302(02)74164-7 